\title{
Inevitability and Necessity to Develop SWFs in China
}

\author{
Jing Xiang, Susheng Wang, Zhaokun Kong \& Wenhu Li \\ Economic and Management Department, Harbin Institute of Technology Shenzhen Graduate School \\ Shenzhen 518055, China \\ E-mail: carol.hsiang@163.com
}

\begin{abstract}
Sovereign Wealth Funds (SWFs) refer to the funds set up by government to manage and operate sovereign wealth. It has important significances for China and global financial system and it also restricts American financial hegemony, which is analyzed in details in this essay. In China, there are huge foreign exchange reserves whose return should be increased in the manner of SWFs. Therefore, it's obviously both inevitable and necessary for China to develop SWFs.

Keywords: SWFs, Foreign exchange reserves, Inevitability, Necessity

Sovereign Wealth is the public assets accumulated by ways of certain tax and budget policy, revenue from natural resources and surplus of balance of payments, controlled and administrated in the form of foreign currencies by government. Sovereign Wealth Funds (SWFs) refer to the funds set up by government to manage and operate sovereign wealth. These years, China's foreign exchange reserve is far beyond normal needs for liquidity and foreign exchange management, and therefore the surplus is invested into multiple assets, even into some securities and financial derivatives. The central bank is bound in duty to make more fortunes for China.
\end{abstract}

\section{Inevitability for SWFs to grow up in China}

(1) American growing deficit in current account is the fundamental cause of SWFs birth and quick expansion. U.S. is the biggest supplier for foreign exchange reserves and SWFs. Its current account deficit drives SWFs to grow up rapidly while providing liquidity for global capital market. Due to the quick expanding deficit, U.S. and other developed countries are compelled to maintain equilibrium of balance of payments through capital surplus, and therefore it is a good chance for China's SWFs to enter America.

\section{Insert Table 1 here}

(2) U.S. dollar continuing depreciation throws rather pressure in maintenance and increment of foreign exchange reserves in countries with large trade surplus, which also speeds SWFs foundation from foreign reserves in some extent. The rate of U.S. dollar to Euro decreases from 1.12 to 0.65 between the year 2002 and 2008, reaching $42 \%$ low. Too much foreign reserves will bring efficiency loss, exchange rate risk, liquidity excess and asset price bubble. It is an urgent task to lower growing speed of foreign reserves and increase their return. What China can do is to adjust policy to protect its foreign reserves. It is an important way to maintain and increase value of foreign exchange reserves by expanding equity investment through SWFs.

(3) China holds huge foreign exchange reserves and should increase their return in the manner of SWFs. By the end of 2007, foreign exchange reserves of China reach 1.53 trillion U.S. dollars and rank first in the world. They are mainly in form of U.S. dollar, for example $70 \%$ of them are invested into U.S. treasury bonds. However, U.S. treasury bonds have no superiority in return except for safety and certain liquidity. From 2001 to 2006, inflation in U.S. is $2.67 \%$ and exchange rate for dollar depreciates $1.53 \%$ in average, making the sum of $4.2 \%$ for both. Only its average nominal rate over $4.2 \%$ can U.S. treasury bonds give investor positive return. In fact, average rate is $2.73 \%$ and $3.46 \%$ for 1 year and 3 year U.S. treasury bonds at the same time, which is smaller than $4.2 \%$. Average rate for 10 year U.S. treasury bonds is $4.49 \%$, higher than $4.2 \%$. However, average return obtained by FDI in China is $22 \%$ (Yu, 2007, pp.11-16). That's to say, China imports obligatory rights with lower return as $4.49 \%$ and exports equity with higher return as $20 \%$ above. The longer this condition continues, the larger damage to China's welfare, so it's necessary to increase return of foreign exchange investments.

\section{Insert Table 2 here}

(4) It is a need to charge off huge foreign exchange reserves by SWFs. Surging of foreign exchange reserves is the fundamental reason for liquidity surplus and capital bubble in China. Base money flows into financial system in the process of open market operation by China central bank. Charge-off, in the ways of lifting deposit reserve rate, issuing 
central bank notes and directional notes, buy-back with special bonds, currency-exchange with commercial banks and so on, is being done, but it's hard to continue for the increasing cost. Capital bubble is becoming clear, and if breaks, it will beat real economy, financial system and household welfare heavily. SWFs help transfer foreign exchange reserves from central bank's balance sheet and release charge-off pressure and liquidity surplus.

(5) Financial globalization creates various channels for SWFs global operation. Firstly, financial globalization makes financial markets much more open and thus it is favorable to capital flow. The smoother the capital flow, the closer the financial co-operation among countries and the more blooming the financial innovation. Also, many countries increase financial market openness, which makes trans-national balance-off possible. There are sound technical instruments and policy foundations for financial capital's massive assembling and flow. Secondly, it enriches categories of financial products and SWFs investments. Various financial derivatives enlarge liquidity; provide various investment choices and hedge means for SWFS. Lastly, it guarantees the orderliness of transnational investment (SWFs) with countries experienced at international investment, which is standardized by global organizations with series of rules etc.

\section{Significances of SWFs for home country}

(1) Risk diversification. Nations relying on export for foreign exchange surplus need to set up SWFs, invest in various ways, increase long-term return, smooth multi-term income, decrease influence brought to economy and fiscal budget by unexpected income fluctuations. Investment diversification disperses risks in consideration of export fluctuations and exchange risk etc. SWFs helps a nation to share global economic rise and decreases reliance on some economy or investment instruments by investing widely in many industries, financial products and various kinds of countries.

(2) Charge-off of liquidity surplus and ease of appreciation pressure from foreign exchange reserves explosion. According to IMF, SWFs is government foreign investment and should be recorded in HP not BOP, which means that foreign exchange assets for mid-and-long term investment by SWFs does not belong to foreign exchange reserves. SWFs, in the form of Investment Companies, issues foreign exchange bonds to domestic market parties to absorb liquidity surplus and then buy foreign exchange reserves from central bank. From standpoint of central bank, this process is able to increase usage of foreign exchange assets, ease appreciation and charge off pressure from continuous explosion of foreign exchange reserves at the same time.

(3) Pursuance for higher investment return of foreign exchange reserves. It's important to use more active investment methods and optimize combinations of risky assets to obtain higher return than traditional management methods. Central banks lay out foreign exchange reserves to high grade government bonds, low-risk currency instruments and so on in old days, whereas SWFs can make multi-investments to get higher revenues.

(4) Support for national development strategy, optimization of resource allocation all over the world, cultivation of world top companies and representation of national benefits in international economic activities. SWFs contributes to the restructure and furtherance of certain national industry. On the one hand, it is national asset arrangement for SWFs. On the other hand, it is about to win some control on global strategic resources, ensuring safety and sustaining development for national economy. Offshore merger and acquisition by SWFs benefit industry upgrade. It's been the mainstream to purchase American equities in international market. Since recent secondary credit crisis and economic depression, it is a good chance to invest in American equities at a lower price. SWFs should be a major force in consideration of need of large money for emerging and acquisition.

(5) Enhancing the capacity in reconstruction of international financial system. Active participation in economic globalization is needed to promote national comprehensive strength and improve economic quality along with China's economic development. By using SWFs as its change of investment policy to participate in international financial market, china will increase discourse rights, remedy unfair international economic and financial order and protect national economic interests.

(6) Prevention of economic crisis and promotion of stable development for economy and society. China holds huge foreign exchange reserves as same as personal preventive saves to cope with economic crisis and development uncertainty. Take Kuwait for example, SWFs managed by investment bureau made important contribution in its reconstruction after Iraqi war.

(7) To guarantee welfare for our offspring by smoothing national assets. There exists a possibility that one day national resources are run out. Therefore, it's farsighted to build up funds with present incomes and leave them to our offspring when the uncertain days come.

\section{SWFs' promotion for international finance situation}

(1) Help stabilize global financial market. SWFs are characterized by long-term investment and low leverage and can stabilize global financial market for following reasons. At first, long-term investment is idle capital not debts, so there is low possibility to liquidate temporarily. Secondly, SWFs is large and usually focuses on gradualness of capital portfolio, which restricts the price reversion. Thirdly, SWFs can increase the depth, width and effectiveness of market and 
decrease the fluctuation of market as well. Further, SWFs adopts buy-and-hold policy as a long-term investor. There are no pressures such as dividend, redemption, investors' dump. So it is not possible to change strategic portfolio under short-term market fluctuation. At last, SWFs is able to allot revenues from primary commodities among countries and enhance market liquidity. SWFs from the world supplied 40 billion U.S. dollars in total to European and American banks in Secondary credit crisis, which makes positive sense in market stabilization.

(2) Change international capital flow direction and market portion. China accumulates large foreign exchange reserves and makes SWFs investment to financial market in developed countries. Developed countries such as U.S. integrate these capitals and invest them into emerging economies. Therefore, SWFs investment in developed countries helps maintain relative equilibrium of global capital flow. But global capital flow will be changed by SWFs when its diversified investment matures.

(3)Drive forward structure adjustment of global financial interests. The rise of China' SWFs will bring a shift in the balance of forces between the east and the west, which has profound impact on global economic geography. By obtaining equities from developed countries with its part of foreign exchange reserves, China is under transition from creditor to equity owner of the developed countries. SWFs are a strong weapon for trade negotiation, technology obtaining and intellectual property rights protecting. Due to its broad investment, not just centralizing in dollar assets, SWFs help to increase other currencies' (especially Euro's) portion in international market, Decrease international economy's dependence on dollar, stabilize the order of international economy. Further, this is promotion for the transfer from monopole (U.S.) to multi-pole (Europe, Asia and Petro-export countries).

\section{Why U.S. worries about SWFs growing-up}

(1) The hegemonic status of dollar is weakened. SWF's explosion is a symbol of emerging countries gaining the world economic status. Assets shift from dollars by SWFs will influence its exchange rate and shake its importance as international currency, and also compel U.S. to implement cautious fiscal policy and deal with trade unbalance. The status of Yean, Euro and Pound will increase at the same time.

(2) Purchase for U.S. government bonds is decreased. Purchasing U.S. government bonds is the main channel for leading countries to deal with their huge foreign exchange reserves and these countries were also primary buyers of U.S. government bonds before the boom of SWFs. In this way, endless foreign exchange flows to American bonds market, which is very important for sustained development of U.S. economy, most important for supply of essential capital to U.S. Both fiscal and trade deficits are the largest factors threatening stability of U.S. macro-economy in recent 30 years. U.S. had to issue bonds continuously to offset the gap of capital. However, SWFs set up by other countries is aiming at diversified foreign exchange investments and a higher return, which means that it will not buy more, even decrease, U.S. government bonds. Then, it will disturb American regular borrowing pattern, even no money for America to borrow.

(3) Financial freedom defined by U.S. is disobeyed. American finance industry is undoubtedly the largest beneficiary of global financial freedom, which is critical reason to promote American financial hegemony. Therefore, U.S. government always drums for financial freedom in both global multilateral trade negotiation and regional bi-lateral trade negotiation. Financial freedom contains many aspects, such as openness of financial market, allowing entrance for foreign countries and openness of capital account and so on, the most critical among which is to eliminate government interference. Obviously, SWFs is against financial freedom. What are U.S. worries is that SWFs controlled by government will not only be pure business, but also political and strategic decisions, thus threatens American benefit.

(4) If SWFs cuts down dollar capital and adds to global equity indices for the need of diversified investment, capital inflow to U.S. will decrease and cause real rate margin increase and dollar depreciation. Moreover, when other countries and private investment institutions learn about this model, it will be a big obstacle for American global financial strategy.

(5) U.S. control on international financial system is shaken. IMF, World Bank, Bank for International Settlements and WTO form international financial system. They usually attend to the need of America and act as agent for American hegemony in global financial system. Presently, international financial organizations such as IMF play a role mainly in exchange rate policy supervision and supply of conditional loans on global financial system and its membership countries. The growing up of SWFs will cut down these two functions and also the control on global financial system by international financial organizations such as IMF etc. Overall, the growing up of SWFs will not only influence international financial condition, but also restricts American financial hegemony for three effects above.

\section{References}

Cai, W. Q. (2007). China SWF's sailing. China Market, 46, 38-39.

Kristian, F. (2007). The Trend and Challenge of Foreign Exchange Reserves Management. Washington: IMF. pp. 2-4.

Li, Y., Yu, W. B., and Zeng, G. (2007). Reformation of China Foreign Exchange Management System under Economy Globalization. Studies of International Finance, 4, 11-16. 
Song, G. Y. (2007). The Rise of Sovereign Wealth Funds and U.S. Financial Hegemony. CONTEMPORARY INTERNAL RELATIONS, 9, 31-33.

Zheng, L. Y. (2008). SWFs' Foreign Investment: Review and Outlook. Studies of International Finance, 6, $14-19$.

Zhong, W. (2007). The Orientation of China National Foreign Exchange Investment Company from Standpoint of SWF. China Development Observation, 9, 39-40.

Zhou, X. H. (2008). The Growing-up and Debate of SWF. International Forum, 1, 17-19.

Table 1. U.S. Current Account Deficit and Analysis of SWFs Source (1987-2007.09) (Unit: 100million U.S. dollar)

\begin{tabular}{|c|c|c|c|c|c|c|}
\hline \multirow[t]{2}{*}{ Year } & \multirow{2}{*}{$\begin{array}{l}\text { Current } \\
\text { Account } \\
\text { Deficit }\end{array}$} & \multirow{2}{*}{$\begin{array}{c}\text { Oil } \\
\text { Commodity } \\
\text { Deficit }\end{array}$} & \multicolumn{4}{|c|}{ Non-oil Commodity Deficit (several east Asian countries) } \\
\hline & & & Japan & China & South Korean & Singapore \\
\hline 1987-1991 & 4714 & 1718 & 2147 & 352 & 296 & 89 \\
\hline $1992-1996$ & 4035 & 2142 & 2812 & 1400 & 82 & 120 \\
\hline $1997-2001$ & 12544 & 5060 & 3411 & 3422 & 380 & 57 \\
\hline $2002-2006$ & 30056 & 7006 & 3827 & 8232 & 481 & -190 \\
\hline $\begin{array}{c}\text { 2007(first } 3 \\
\text { quarters) }\end{array}$ & 5615 & 2314 & 762 & 2141 & 80 & -147 \\
\hline total & 57344 & 10270 & 12004 & 15506 & 1004 & -78 \\
\hline
\end{tabular}

Source: relation statistics from Department of Commerce, U.S.

Table 2. The Comparative Analysis of Capital Return Invested in U.S. (2001-2006) （unit: \%)

\begin{tabular}{|c|c|c|c|c|c|c|c|c|}
\hline year & $\begin{array}{c}\text { U.S. } \\
\text { CPI }\end{array}$ & $\begin{array}{c}\text { Exchange } \\
\text { rate of } \\
\text { dollar } \\
\text { of direct } \\
\text { investment in } \\
\text { U.S. }\end{array}$ & $\begin{array}{c}\text { Return rate } \\
\text { Company } \\
\text { bonds }\end{array}$ & $\begin{array}{c}\text { Rate of 1 } \\
\text { year } \\
\text { government } \\
\text { bonds }\end{array}$ & $\begin{array}{c}\text { Rate of 3 } \\
\text { years } \\
\text { government } \\
\text { bonds }\end{array}$ & $\begin{array}{c}\text { Rate of 10 } \\
\text { years } \\
\text { government } \\
\text { bonds }\end{array}$ & $\begin{array}{c}\text { Rate of 20 } \\
\text { years } \\
\text { government } \\
\text { bonds }\end{array}$ \\
\hline 2001 & 2.8 & 5.4 & 0.9 & 7.08 & 3.45 & 4.09 & 5.02 & 5.63 \\
\hline 2002 & 1.6 & 0.6 & 2.9 & 6.49 & 1.72 & 3.10 & 4.61 & 5.43 \\
\hline 2003 & 2.3 & -6.0 & 4.3 & 5.66 & 1.68 & 2.10 & 4.01 & 4.96 \\
\hline 2004 & 2.7 & -4.6 & 6.2 & 5.63 & 1.61 & 2.72 & 4.24 & 5.04 \\
\hline 2005 & 3.4 & -2.6 & 6.5 & 5.13 & 3.50 & 3.93 & 4.29 & 4.61 \\
\hline 2006 & 3.2 & -2.0 & -- & 5.91 & 3.60 & 4.27 & 4.8 & 5.00 \\
\hline average & 2.67 & -1.53 & 4.26 & 5.95 & 2.73 & 3.46 & 4.49 & 5.11 \\
\hline
\end{tabular}

Source: Song Guoyou. (2007). The Rise of Sovereign Wealth Funds and U.S. Financial Hegemony. CONTEMPORARY INTERNAL RELATIONS. 